\title{
TARAXACUM SCANICUM DAHLST. GROUP (SECTION ERYTHROSPERMA) IN POLAND: CHOROLOGY AND SEED AND POLLEN MORPHOLOGY OF THE MICROSPECIES
}

\author{
Jolanta MARCINIUK $^{1 *}$, RADIM J. VAŠUt ${ }^{2}$, PAWE⿺ MARCINIUK ${ }^{1}$, ANETA CZARnA ${ }^{3}$ \\ ${ }^{1}$ Department of Botany, University of Podlasie \\ Prusa 12, 08-110 Siedlce, Poland \\ *e-mail: jolam@ap.siedlce.pl \\ 2 Department of Botany, Faculty of Science \\ Šlechtitelů 11, 78371 Olomouc, Czechia \\ e-mail: radim.vasut@upol.cz \\ ${ }^{3}$ Department of Botany, Agricultural University \\ Wojska Polskiego 71 C, 60-625 Poznań, Poland
}

(Received: June 16, 2008. Accepted: March 10, 2009)

\begin{abstract}
The genus Taraxacum is taxonomically complicated due to apomixis. Therefore, there are significant differences in knowledge of regional Taraxacum-Floras among European countries. Similarly, some taxa are well characterised with well-known distribution, whereas some ones are known e.g. from a single locality. Taraxacum scanicum of section Erythrosperma is one of the most common microspecies of this section in Europe. Recently, this taxon was split into three microspecies. In this study we map the distribution of three described taxa of this group in Poland, i.e. T. scanicum s.s., T. prunicolor and T. cristatum. The survey showed that $T$. scanicum has a similar distribution as T. prunicolor in Poland. This is in contrast with the hitherto known distribution of both taxa. T. cristatum was found at a single locality that is quite distant from the distribution in southern central Europe. We also provide with new morphological characteristics of achenes and pollen for T. scanicum s.s. and T. prunicolor.
\end{abstract}

KEY WORDS: dandelion, geographical distribution, pollen morphology, seed sculpture, SEM, Taraxacum sect. Erythrosperma.

\section{INTRODUCTION}

The genus Taraxacum Wigg. is taxonomically one of the most problematic genera in native European flora. It is caused by an apomictic mode of reproduction of all dandelion polyploids, i.e. by meiotic diplospory (Asker and Jerling 1992). The genus comprises over 2500 species grouped in ca. 55 sections (Kirschner and Štěpánek 1997, 2004; Kirschner et al. 2003; Uhlemann et al. 2004). Vast majority of described taxa are apomictic microspecies. Unfortunately, Taraxacum specialists have only limited information on distribution and relationship on relatively large number of apomictic microspecies described in the past and in some cases it takes strong effort to re-define these taxa (Lundevall and Øllgaard 1999). It also was caused by the fact that many Taraxacum microspecies were described from single locality (or a few localities) without knowing its real morphological plasticity and the relationship to other taxa. Due to this lack of information, many species records for regional floras were erroneous and therefore often these data require a critical revision.

From the territory of Poland, a total of 369 species belonging to 13 sections have been recorded up till now (Głowacki 2004). In terms of cytogeography, Poland belongs to the zone in which Taraxacum apomictic polyploid cytotypes absolutely prevail (den Nijs et al. 1990). Sexually reproducing diploids are represented in Poland by only three species occurring in single localities: Taraxacum bessarabicum (Hornem.) Hand.-Mazz. of section Piesis A. J. Richards - reported from Wolica Siesławska near Busko, leg. Jasiewicz, det. van Soest (Tacik 1980); Taraxacum pieninicum Pawł. of section Erythrocarpa Hand.-Mazz. endemic for Pieniny Mts., extinct at locus classicus (Zarzycki 1993), found again in 1999 (Wróbel 2004); and Taraxacum erythrospermum Andrz. of section Erythrosperma (H. Lindb.) Dahlst. - reported from Pieniny Mts. as T. canophyllum van Soest (Małecka 1985). Presence of diploid species of section Ruderalia Kirschner et al., i.e. T. lineari- 
squameum van Soest, was not observed in Poland so far. Although its occurrence there is highly probable, because it grows in Moravian Silesia at the border with Poland (Kirschner et al. personal communication).

The latter mentioned section, i.e. T. sect. Erythrosperma, is a group of dandelions confined to dry and xerothermic habitats. A total of ca. 150 species is growing across the Europe eastwards to Western Asia. Several species are also native to Poland - a total of 23 species of lesser dandelions were recorded from its territory so far (Mirek et al. 2002).

One of the most common European Erythrosperma-species is Taraxacum scanicum Dahlst. It is known to be distributed across major part of N, W and central Europe (van Soest 1957; Doll 1973; Uhlemann 1996, 2003; Dudman and Richards 1997; Wendt 2001; Kallen et al. 2003; Vašut 2003). The latter author recognized during his research that the taxon traditionally recognized as $T$. scanicum is not morphologically homogenous in central Europe; in fact it can be split into seven different $T$. scanicum-like morphotypes (Vašut 2003). Two of them were recognized as morphologically well-separated taxa from the real Taraxacum scanicum and having a large distribution area. Therefore, they were recently described as new species, i.e. $T a$ raxacum prunicolor $\mathrm{M}$. Schmid, Vašut et Oosterveld (Schmid et al. 2004) and Taraxacum cristatum Kirschner, Štěpánek et Vašut (Vašut et al. 2005). Furthermore, these taxa are genetically separated from $T$. scanicum s.s. as well (Vašut et al. 2004). Remaining known morphotypes are known from a lesser number of localities and its plasticity is not well characterized so far - these morphotypes are still under study. In addition, it seems that to this group also belongs the Taraxacum bellicum Sonck described from Inari in Finland (Sonck 1983). However, due to lack of herbarium material of good quality and because the species is probably extinct in type locality (H. Øllgaard, in litt.), we were not able to identify this unilocal species with any of our known morphotypes. Taraxacum bellicum therefore remains a single locality species of not well known characteristics. According to original description and available herbarium material, it seems that its position is apparently somehow halfway between $T$. scanicum and T. prunicolor.

Taraxacum scanicum was repeatedly recorded from Poland in the past (Małecka 1967, 1969; Øllgaard et al. 2000, 2002a, 2002b; Głowacki and Czarna 2003; Głowacki et al. 2004). Our study aimed at revision of Taraxacum scanicum group in Poland in the light of new investigations. In this paper we present the distribution of all three well-characterized species of T. scanicum group in Poland and provide with new delimitations of their species distribution area. We also give new specific determination characteristics between T. scanicum and T. prunicolor based on seed and pollen morphology using SEM microscopy.

\section{MATERIALS AND METHODS}

The distribution of the taxa was studied in the field exclusively, in selected regions of Poland, i.e. in Eastern Poland (Southern Podlasie Lowland, and the Biebrza River Valley); and in the Wielkopolska region in 2004-2005. We present it in an ATPOL grid map (10×10 km squares) of Poland (Zając and Zając 2001). Only the described and properly known taxa were taken into consideration (i.e. $T$. scanicum s.s., T. prunicolor and T. cristatum). Morphology of pollen grains and achenes of Taraxacum scanicum and T. prunicolor was studied using Scanning Electron Microscopy (SEM). T. cristatum was not included due to its very rare occurrence in Poland and lack of material. It was performed in the Electron Microscopy Laboratory, Faculty of Biology at A. Mickiewicz University in Poznań. We measured both the inner (without exin) and outer diameter in polar position for 100 pollen grains of each species. We sampled pollen grains from closed capitulas, just before their opening and treated in $10 \% \mathrm{KOH}$. We measured the diameter using microscope ocular micrometer, at $1.5 \times 10 \times 40$ magnification (micrometric constant -1.1 ).

\section{RESULTS}

\section{Morphology}

The Taraxacum scanicum group comprises morphologically similar species. However, they are well separated from each other. Superficially, plants having prolonged lingulate terminal lobe, quite short and slightly recurved lateral lobes, narrow achenes, and slightly bordered outer involucral bracts were traditionally recognized as $T$. scanicum s.s. Recent investigations showed remarkable differences among the taxa (Schmid et al. 2004; Vašut et al. 2005). Updated overview, based on observation on Polish material, is summarized in Table 1.

TABLE 1. Main differences between Taraxacum scanicum s.s., T. prunicolor and T. cristatum.

\begin{tabular}{llll}
\hline Characteristics & T. scanicum s.s. & T. prunicolor & T. cristatum \\
\hline Flower head & convex & slightly convex & convex \\
Inner flowers & tips reddish & tips yellow & tips yellow \\
Outer bracts & spreading & regularly recurved! & spreading \\
Colour of outer bracts & green & purple! & pale green (becoming pink) \\
Border of outer bracts & distinct $(0.1-0.2 \mathrm{~mm})$ & very narrow $(<0.1 \mathrm{~mm}) !$ & distinct $(0.1-0.2$ mm) \\
Upper lobe & teethed & usually smooth! & teethed \\
Lateral lobes & $4-6$, distinctly teethed to sublaciniate! & $3-5(-6)$ smooth to slightly teethed & $2-4$ teethed! \\
Achenes - length & $3.5-4$ mm & $3.2-3.6$ mm! & $(3.5-) 3.7-4.2(-4.6)$ mm \\
Achenes - spines & distinct, regular & more or less distinct & distinct \\
Achenes - color & red-brown! & brown &
\end{tabular}



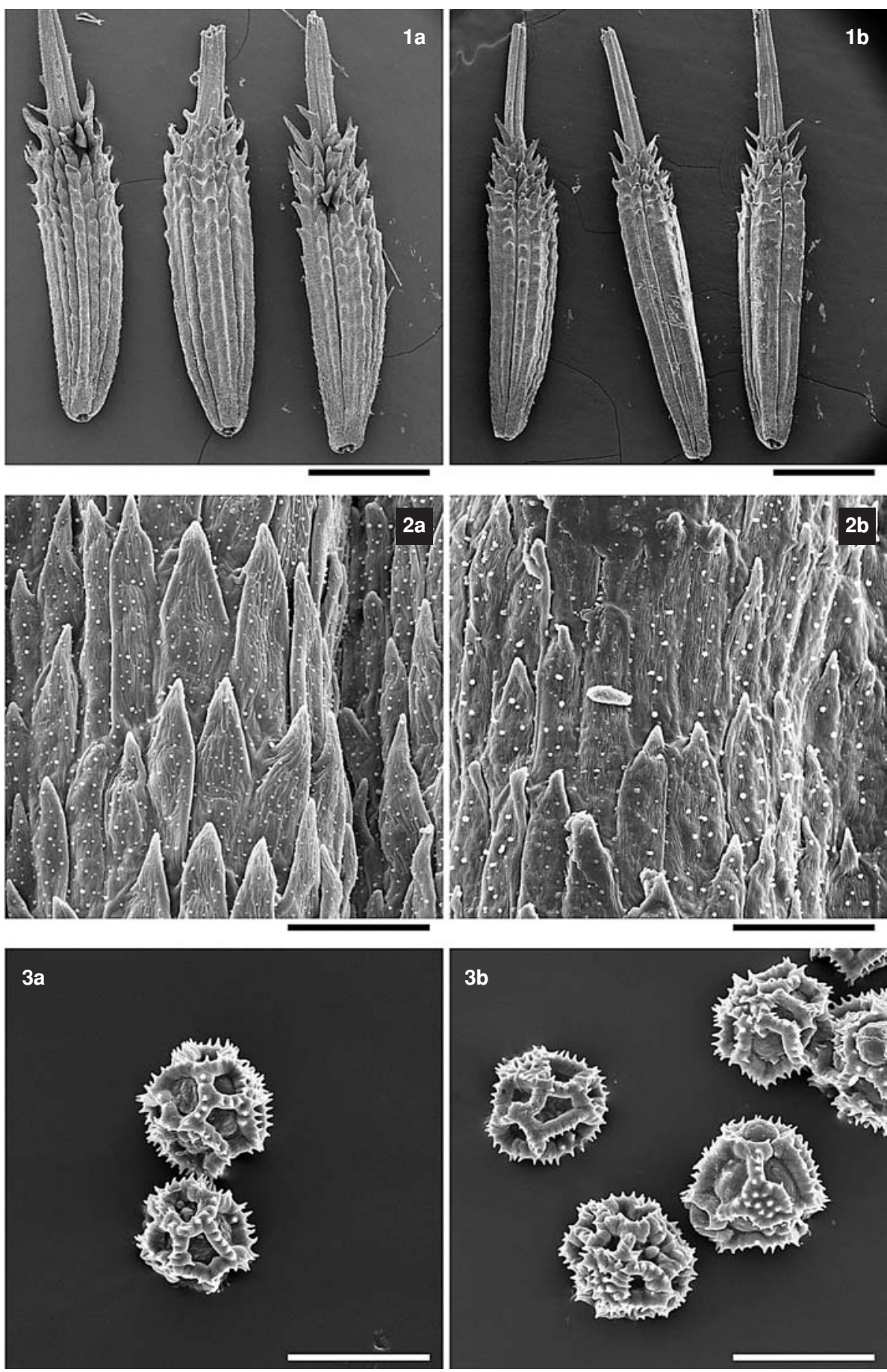

Fig. 1. SEM photographs of specific characters of (a) Taraxacum scanicum and (b) $T$ prunicolor. 1: Mature achenes. Bar $=1 \mathrm{~mm}$. Fig. 2. Detail of achene spines in upper part of the seed. Bar $=30$ um. Fig. 3. Pollen grains of yet unopenned capitulus. $\mathrm{Bar}=30 \mu \mathrm{m}$.

\section{Achenes}

The achenes of Taraxacum scanicum s.s. and Taraxacum prunicolor differ not only in their colour and size but also in design of achene, i.e. in its sculpture, size and number. Taraxacum scanicum s.s. shows distinct longitudinal ribs and abundant regular spines covering about $1 / 3$ of upper achene surface (Fig. 1). The achenes of Taraxacum prunicolor show slight ribbing, spines scarce and distinctly irregular, covering about 1/4 of upper achene surface (Fig. 1).

\section{Pollen grains}

The pollen of Taraxacum scanicum s.s. and Taraxacum prunicolor shows very similar morphology. However, it seems that the pollen grains of Taraxacum scanicum s.s. are less variable in size of diameter then those of $T$. prunicolor. It also shows more distinct spines (Fig. 1). The results of pollen measurements indicate that the average diameter, and its variability differs between the species (Fig. 2). The average maximum diameters of Taraxacum scanicum s.s. pollen were: inner (without exin) $22.48 \mu \mathrm{m}$, and outer $33.83 \mu \mathrm{m}$. Variability was relatively low - the inner diameter ranged within14.3-30.8 $\mu \mathrm{m}$, and $78 \%$ of pollen grains showed diameters from 20.1 to $25 \mu \mathrm{m}$. In case of outer diameter, variability was similar - (17.6) 26.4-40.7 $\mu \mathrm{m}$, but no distinct modal value was observed. The pollen grains of Taraxacum prunicolor were larger - the average inner diameter was $24.76 \mu \mathrm{m}$, and outer $-35.90 \mu \mathrm{m}$. Their size was also more variable: inner diameter ranged from 9.9 to 44 $\mu \mathrm{m}$, and outer - from 15.4 to $56.1 \mu \mathrm{m}$. These differences might be results of differently interrupted meioses in both species - it is known that different apomictic dandelion clones differ in pollen fertility and diameter variability, as 

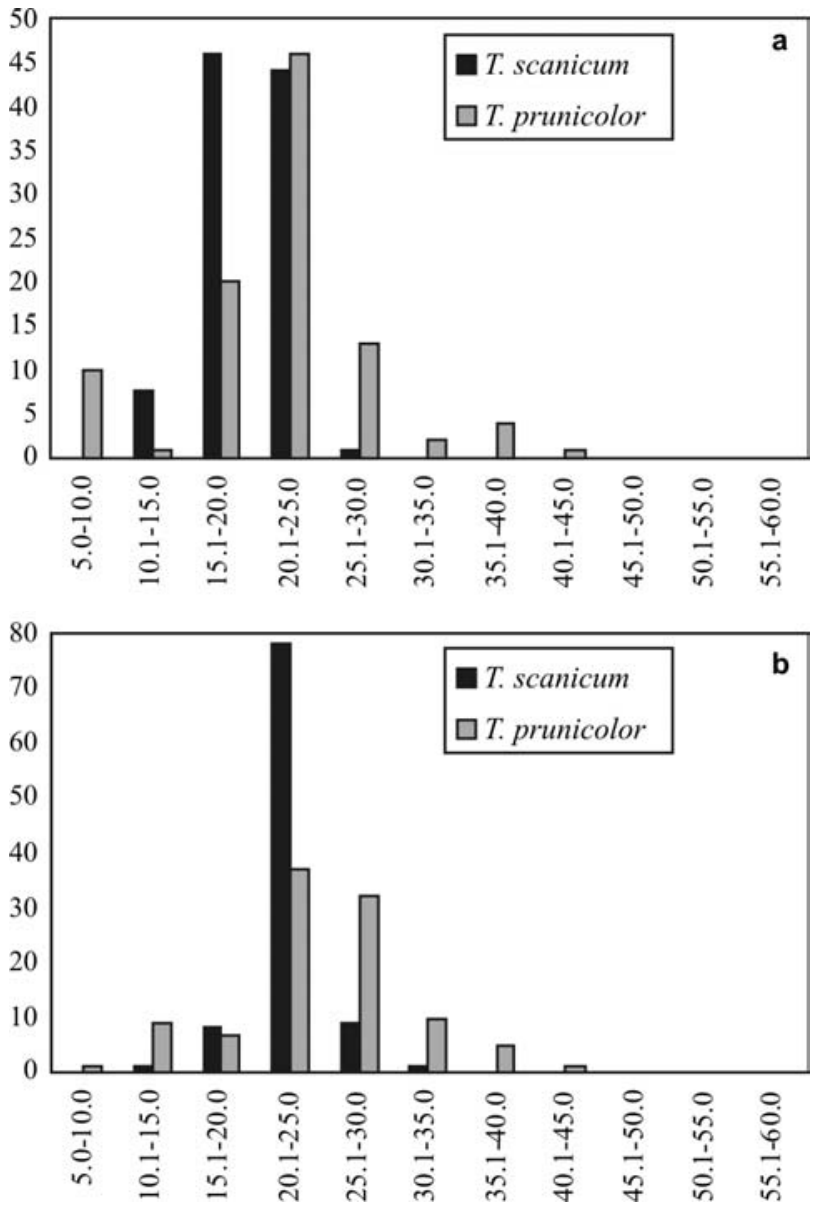

Fig. 2. Distribution of sizes of polen grains in T. scanicum s.s. and T. prunicolor: $\mathrm{a}$ - outer diameter; $\mathrm{b}$ - inner diameter (without exine).

a consequence of genome mosaic structure (Vašut et al. personal communication).

\section{Distribution of taxa in Poland}

Taraxacum scanicum Dahlst. s.s.

Arkiv Bot. 10(11): 21. 1911. - Type: Sweden, Skåne, Lund, the garden of the infectious-diseases hospital, 21. 5. 1910, E. L. Ekman, det. H. Dahlstedt. [upper specimen] (lectotype: S; selected by Lundevall and Øllgaard 1999).

Taraxacum scanicum is western a European species that is common in W and NW Europe (from France to Scandinavia). The occurrence of the species becomes sparser towards the East. Regions of decreased number of localities of $T$. scanicum are overlapping with regions of increased number of $T$. prunicolor localities. This line passes through Poland as well. However, we have found that the distribution of T. scanicum and T. prunicolor is similar in Poland. Recently confirmed localities of $T$. scanicum in Poland filled the gap in the species distribution between in Germany and Czechia (Uhlemann 1996, 2003; Kallen et al. 2003; Vašut 2003) and the Baltic countries (H. Øllgaard, in litt.; Trávníček, in litt.). We found $T$. scanicum at 12 localities, mainly in W Poland (11 localities out of 12).

Newly discovered localities in Poland (Fig. 3a):

1. Ławki Swamp, FB96, The Biebrzański National Park, wet meadow 9.05.2004, leg. J. Marciniuk, det. R. J. Vašut 2004.
2. Tursko, commune Gołuchów, CD65, roadside near pine forest, leg. A. Czarna 26.05.2005, det. R. J. Vašut 2005.

3. Orlina Duża, commune Gizałki, CD45, roadside in pine forest, leg. A. Czarna 14.05.2005, det. R. J. Vašut 2005.

4. Cicha Góra, commune Nowy Tomyśl, BD13, pine forest border, leg. A. Czarna 2.05.2005, det. R. J. Vašut 2005.

5. Jastrzębsko, commune Nowy Tomyśl, BD12, roadside, near forest, leg. A. Czarna 2.05.2005, det. R. J. Vašut 2005.

6. Grubsko, commune Nowy Tomyśl, BD12, Protestant cemetery, leg. A. Czarna 2.05.2005, det. R. J. Vašut 2005.

7. Lasówki, commune Grodzisk Wielkopolski, BD24, roadside, and Robinia forest near pine forest, leg. A. Czarna 24.04.2005, det. R. J. Vašut 2005.

8. Stara Dąbrowa, commune Kuślin, BD04, pine forest border, leg. A. Czarna 10.05.2005, det. R. J. Vašut 2005.

9. Myszkówek, commune Zagórów, CD35, roadside, leg. A. Czarna 16.05.2005, det. R. J. Vašut 2005.

10. Murzynowo Leśne, commune Krzykosy, CD31, roadside, near forest, leg. A. Czarna 11.05.2005, det. R. J. Vašut 2005

11. Trzcianki, commune Pyzdry, CD34, forest roadside, leg. A. Czarna 16.05.2005, det. R. J. Vašut 2005.

12. Żdżary, commune Zagórów, CD35, roadside near pine forest, leg. A. Czarna 16.05.2005, det. R. J. Vašut 2005.

Taraxacum prunicolor M. Schmid, Vašut et Oosterveld

Feddes Repert. 115(3-4): 221. 2004. - Type: Germany, North-Bavaria (Middle Franconia): Erlangen, scattered sandy places under pinewood at the Erwin-Rommel-Wohnheim "Uni-Südgelände", 300 m, 1. V. 2002, M. Schmid (holotype M; isotypes M, PRA, OL, L, STU, DR and W).

Taraxacum prunicolor is one of the commonest species of section Erythrosperma in southern part of Central Europe, it is quite common especially in Bavaria, Bohemia and Moravia. It was known to distribute also in northern parts of that region; and it was known from Moravian Silesia, very close to the Polish border. We therefore expected its presence in Poland as we, confirmed at 16 localities, in this study. Newly discovered localities in Poland represent the northern border of the species distribution area. $T$. prunicolor is a very remarkable species due to presence of reddishviolet and regularly recurved outer involucral bracts. The species has brown achenes in contrast to $T$. scanicum s.s.

Distribution in Poland (Fig. 3b):

1. Bużyska, FD07, The Podlasie Bug Gorge, psammophilous grassland in the Bug River valley, leg. J. and P. Marciniuk 10.05.2003, det. R. J. Vašut 2004.

2. Bużka, FD09, The Podlasie Bug Gorge, meadow in the Sarenka River valley, leg. J. and P. Marciniuk 2.05.2004, det. R. J. Vašut 2004.

3. Goniądz, FB77, The Goniądz Plateau, The Biebrzański National Park, Sedo-Scleranthetea grassland, leg. J. Marciniuk 9.05.2004, det. R. J. Vašut 2004.

4. Mścichy, FB86, The Biebrza Basin, The Biebrzański National Park, Biebrza dike, leg. J. Marciniuk 8.05.2004, det. R. J. Vašut 2004. 

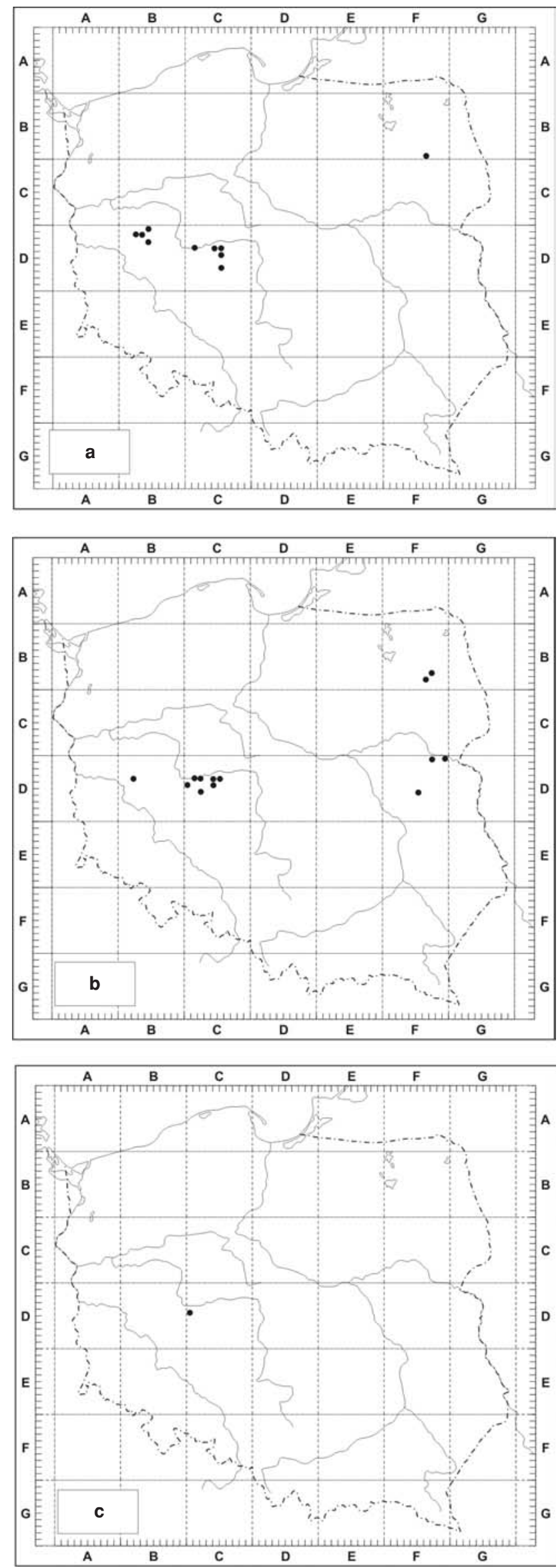

Fig. 3. Distribution of taxa of Taraxacum scanicum group in Poland: a $T$. scanicum s.s.; b $-T$. prunicolor; $\mathrm{c}-T$. cristatum.
5. Żdżary, FD55, The Łuków Plain, sandy roadside, leg. J. and P. Marciniuk 13.05.2004, det. R. J. Vašut 2004.

6. Świętomierz, commune Nowe Miasto on the Warta River, CD32, roadside, leg. A. Czarna 2.05.2003, det. R. J. Vašut 2004.

7. Rogusko, commune Nowe Miasto upon Warta CD32, sandy roadside in pine forest, leg. A. Czarna 10.05.2003, det. R. J. Vašut 2004.

8. Jarosławki, commune Książ Wielkopolski, CD40, pine forest roadside, E from the village, leg. A. Czarna 21.05.2003, det. R. J. Vašut 2004.

9. Murzynowo Leśne, commune Krzykosy, CD31, Robinia forest $2 \mathrm{~km}$. S from the village, leg. A. Czarna 10.05.2003, det. R. J. Vašut 2004.

10. Nowe Miasto upon Warta, CD32, sandy roadside in pine forest, leg. A. Czarna 10.05.2003, det. R. J. Vašut 2004.

11. Jarocin, commune Jarocin, CD52, old Protestant cemetery, leg. A. Czarna 8.05.2003, det. R. J. Vašut 2004.

12. Solec, commune Krzykosy, CD31, the Warta River levee, leg. A. Czarna 10.05.2003, det. R. J. Vašut 2004.

13. Tomice near Pyzdry, CD34, sandy roadside near pine forest, leg. A. Czarna 14.05.2005, det. R. J. Vašut 2005.

14. Korzwy, commune Gizałki, CD44, Protestant cemetery No 110, leg. A. Czarna 14.05.2005, det. R. J. Vašut 2005.

15. Siedlec, commune Siedlec, BD32, mixed forest border, leg. A. Czarna 19.04.2005, det. R. J. Vašut 2005.

16. Żdżary, commune Zagórów, CD35, roadside near pine forest, leg. A. Czarna 16.05.2005, det. R. J. Vašut 2005.

Taraxacum cristatum Kirschner, Štěpánek et Vašut

Preslia 77(2): 204. 2005. - Type: Slovakia, district of Rožňava, Krásnohorské Podhradie (Krasznahorkaváralja), in xerothermic grasses near Krásna Hôrka castle, 1. V. 2004, R. J. Vašut and M. Vašutová (holotype PRA; isotypes OL, PRC and herb. R. J. Vašut).

Taraxacum cristatum is a delicate plant that is distributed in southern part of central Europe, especially in southern Bohemia and Moravia (Czechia), Austria, and southern Slovakia and Hungary (Vašut et al. 2005). It is even missing in the northern regions of Czechia and Slovakia (in contrast to $T$. prunicolor). Morphologically it is closer to $T$. prunicolor, but differs mainly by character of leaves and character of outer involucral bracts that are spreading and green. We found this species at a single locality in Poland that is quite far away from its continuous distribution in southern central Europe. We suppose it might be introduced here.

Distribution in Poland (Fig. 3c):

1. Książ Wielkopolski, CD40, SW Poland, Robinia forest in N part of the town "Torfica", leg. A. Czarna 2000, 2003, det. R. J. Vašut.

Taraxacum bellicum C. E. Sonck

Mem. Soc. Fauna Flora Fenn. 59(1): 1. 1983. - Type: Finnland, Lapponia inarensis, Inari, Kirkonkylä, Miesniemi, 7. VII. 1981, C. E. Sonck (holotype H; isotypes herb. C. E. Sonck and herb. H. Øllgaard). 
$T$. bellicum is a rather unknown taxon. It was described from a single locality and no further distribution is known. Furthermore, this locality served as a German military camp in WWII and very likely this species was introduced here. This was apparently the idea behind the description of this taxon supposing that it might found somewhere in central Europe later on. Unfortunately, the ecological conditions are not optimal for taxa of the section Erythrosper$m a$ there, which makes the identification even harder. However, it is known that German Army collected the hay for horses also in central Europe when moving to Scandinavia (Øllgaard 2003). We therefore aimed at finding some similar morphotypes to T. bellicum in Poland. Actually we found at one locality plants that resemble a Holotype plant of T. bellicum from its original description in more aspects: i.e. especially having reddish fruits and having leaves with lateral lobes less dentate than $T$. scanicum, but more dentate than $T$. prunicolor. The second author therefore cultivated this plant in standard conditions together with all three other related microspecies in order to see the plasticity of the plant (in garden of the Netherlands Institute of Ecology, Heteren, NL; under No. RJV.E75). It turned out that this morphotype similar to T. bellicum was in fact $T$. scanicum s.s. Unfortunately, $T$. bellicum still remains to be known from a single locality only. We also cannot exclude that it represents an extreme form of T. scanicum s.s. that is very common in both northern Germany (Kallen et al. 2003; Uhlemann 1996, 2003) and western Poland.

\section{Identification key}

to Taraxacum scanicum group species in Poland

Morphological characteristics of T. scanicum s.s., T. prunicolor and T. cristatum are based on our observations on living plants. Morphological characteristics of T. bellicum are according to original description (Sonck 1983).

1a Achenes red-brown, distal margins of lateral lobes and interlobia remarkably dentate to sublaciniate.

b Achenes brown, distal margin of lateral lobes and interlobia entire or shortly denticulate.

2a distal margins of lateral lobes often deeply sublaciniate. T. scanicum

b distal margins of lateral lobes narrowly dentate T. bellicum

3a Number of lateral lobes 3-5; lingulate terminal lobes flat; outer involucral bracts regularly recurved beneath the involucrum, reddish-violet; scapes during flowering longer than leaves T. prunicolor

b Number of lateral lobes 2-4; lingulate terminal lobes recurved; outer involucral bracts irregularly spreading to recurved beneath the involucrum, glaucous green; sometimes pinkish; scapes during flowering equal to or shorter than leaves T. cristatum

\section{ACKNOWLEDGEMENTS}

We want to thank Dr. Bohumil Trávníček (Olomouc, Czechia) for his useful comments on the manuscript and $\mathrm{H}$. Øllgaard (Viborg, Denmark) for information on and for images of Taraxacum bellicum from the type locality. The second author was partially supported by grant from the Ministry of Education, Youth and Sport of the Czech Republic (MSM 6198959215).

\section{LITERATURE CITED}

ASKER S.E., JERLING L. 1992. Apomixis in plants. CRC Press, Boca Raton.

DOLL R. 1973. Revision der sect. Erythrosperma Dahlst. emend. Lindb. f. der Gattung Taraxacum Zinn. 2. Teil. Feddes Repert. 84: 1-180.

DUDMAN A.A., RICHARDS A.J. 1997. Dandelions of Great Britain and Ireland. BSBI Handbook No. 9, London.

GŁOWACKI Z., CZARNA A. 2003. Gatunki rodzaju Taraxacum (Asteraceae) z terenu Wielkopolski (Taraxacum species (Asteraceae) in Wielkopolska (mid-western Poland)). Acta Sci. Pol. Biologia 2(1-2): 51-54. (in Polish with English summary)

GŁOWACKI Z. 2004. Morfologia i taksonomia rodzaju Taraxacum (Asteraceae) (Morphology and taxonomy of the genus Taraxacum (Asteraceae). Fragm. Flor. Geobot. Polonica Suppl. 6: 59-64. (in Polish with English summary)

GŁOWACKI Z., ØLLGAARD H., KRECHOWSKI J. 2004. Genus Taraxacum in the herbarium of University of Silesia. Bad. Fizjogr. Pol. Zach. Botanika 53: 107-112.

KALLEN H.W., KALLEN C., SACKWITZ P., ØLLGAARD H. 2003. Die Gattung Taraxacum (Asteraceae) in Norddeutschland - 1. Teil: Die Sektionen Naevosa, Celtica, Erythrosperma und Obliqua. Bot. Rundbr. Meckl.-Vorp. 37: 5-89.

KIRSCHNER J., ŠTĚPÁNEK J. 1997. A nomenclatural checklist of supraspecific names in Taraxacum. Taxon 46: 87-98.

KIRSCHNER J., ŠTĚPÁNEK J. 2004. New sections in Taraxacum. Folia Geobot. 39: 259-274.

KIRSCHNER J., ŠTĚPÁNEK J., MES T.H.M., den NIJS J.C.M., OOSTERVELD P., ŠTORCHOVÁ H., KUPERUS P. 2003. Principal features of the cpDNA evolution in Taraxacum (Asteraceae, Lactuceae): a conflict with taxonomy. Pl. Syst. Evol. 239: 231-255.

LUNDEVALL C.F., ØLLGAARD H. 1999. The genus Taraxacum in the Nordic and Baltic countries: Types of all specific and varietal taxa, including type locations and sectional belonging. Preslia 71: 43-171.

MAŁECKA J. 1967. Cytoembriological studies in Taraxacum scanicum Dt. Acta Biol. Cracov. Series Botanica 10: 195-206.

MAŁECKA J. 1969. Further cyto-taxonomic studies in the genus Taraxacum section Erythrosperma Dt. I. Acta Biol. Cracov. Series Botanica 12: 57-70.

MAŁECKA J. 1985. Cyto-embryological studies in a diploid species Taraxacum canophyllum v. S. (Section Erythrosperma Dt.). Acta Biol. Cracov. Series Botanica 27: 83-88.

MIREK Z., PIĘKOŚ-MIRKOWA H., ZAJĄC A., ZAJĄC M. 2002. Flowering plants and pteridophytes of Poland. A checklist. In: Z. MIREK (ed.), Biodiversity of Poland 1: 1-442, W. Szafer Institute of Botany, Polish Academy of Sciences, Kraków.

den NIJS J.C.M., KIRSCHNER J., ŠTĚPÁNEK J., VAN DER HULST A. 1990. Distribution of diploid sexual plants of Taraxacum sect. Ruderalia in east-Central Europe, with special reference to Czechoslovakia. Pl. Syst. Evol. 170: 71-84.

ØLLGAARD H. 2003. New species of Taraxacum, sect. Ruderalia, found in Central and Northern Europe. Preslia 75: 137164.

ØLLGAARD H., GŁOWACKI Z., GRUŻEWSKA T. 2002a. Gatunki rodzaju Taraxacum Wigg. w Kotlinie Biebrzańskiej i Dolinie Dolnej Narwi. Drozdowskie Zesz. Przyr. 2: 9-58. (in Polish)

ØLLGAARD H., GŁOWACKI Z., KRECHOWSKI J. 2000. Gatunki rodzaju Taraxacum (Asteraceae) w Polsce. Cz. 1. Pomorze, Mazowsze i Podlasie. Fragm. Flor. Geobot. Polonica 7: 5-62. (in Polish with English summary) 
ØLLGAARD H., GŁOWACKI Z., FALKOWSKI M., KRECHOWSKI J. 2002b. Gatunki rodzaju Taraxacum (Asteraceae) w Polsce. Cz. 2. Fragm. Flor. Geobot. Polonica 9: 3-20. (in Polish with English summary)

SCHMID M., VAŠUT R.J., OOSTERVELD P. 2004. Taraxacum prunicolor $\mathrm{sp}$. nova, a new species of the Taraxacum scanicum group (sect. Erythrosperma). Feddes Repert. 115: 220-229.

van SOEST J.L. 1957. Taraxacum sectio Obliqua Dt. en sectio Erythrosperma Dt. em. Lb. in Nederland. Acta Bot. Neerl. 6: 74-92.

SONCK C.E. 1983. Zwei neue Taraxacum-Arten aus dem nördlichen Lappland. Mem. Soc. Fauna Flora Fenn. 59: 1-7.

TACIK T. 1980. Taraxacum Wiggers, Mniszek (Dmuchawiec). In: A. Jasiewicz (ed.), Flora polska. Rośliny naczyniowe Polski i ziem ościennych. 14: 7-199. Państwowe Wydawnictwo Naukowe, Warszawa-Kraków. (in Polish)

UHLEMANN I. 1996. Zur Taraxacum-Flora von Sachsen I. Ber. Arbeitsgem. Sächs. Bot. N. F. 15: 39-85.

UHLEMANN I. 2003. Die Gattung Taraxacum (Asteraceae) im östlichen Deutschland. Mitt. Florist. Kart. Sachsen-Anhalt, Sonderheft 2003: 1-136.

UHLEMANN I., KIRSCHNER J., ŠTĚPÁNEK J. 2004. The genus Taraxacum (Asteraceae) in the Southern Hemisphere. I. The section Antarctica Handel-Mazzetti and notes on dandelions of Australasia. Folia Geobot. 39: 205-220.
VAŠUT R.J. 2003. Taraxacum sect. Erythrosperma in Moravia (Czech Republic): Taxonomic notes and the distribution of previously described species. Preslia 75: 311-338.

VAŠUT R.J., ŠTĚPÁNEK J., KIRSCHNER J. 2005. Two new apomictic Taraxacum microspecies of the section Erythrosperma from Central Europe. Preslia 77: 197-210.

VAŠUT R.J., van DIJK P.J., FALQUE M., TRÁVNÍČEK B., de JONG J.H. 2004. Development and characterisation of nine new microsatellite markers in Taraxacum (Asteraceae). Mol. Ecol. Notes. 4: 645-648.

WENDT G. 2001. Guide till sandmaskrosor och dvärgmaskrosor (sektionera Erythosperma och Obliqua). Svensk. Bot. Tidskr. 95: 94-114. (in Swedish with English summary)

WRÓBEL I. 2004. Mniszek pieniński Taraxacum pieninicum Pawł. - gatunek specjalnej troski w Pienińskim Parku Narodowym. Chrońmy Przyr. Ojcz. 2: 11-16. (in Polish with English summary)

ZAJĄC A., ZAJĄC M. (eds). 2001. Atlas rozmieszczenia roślin naczyniowych Polski. Nakładem Pracowni Chorologii Komputerowej Instytutu Botaniki UJ, Kraków. (in Polish and English)

ZARZYCKI K. 1993. Taraxacum pieninicum Pawł. In: K. Zarzycki, R. Kaźmierczakowa (eds), Polska Czerwona Księga Roślin. p. 196. Inst. Bot. i Inst. Ochr. Przyr. PAN, Kraków. (in Polish) 